\title{
PENCEGAHAN ANJLOKAN TERKAIT PERUBAHAN TRACK LAY OUT BARU DI STASIUN MANGGARAI
}

\author{
Ir. Joko Septanto, MT \\ Dosen STTD \\ J1. Raya Setu No. 89, Bekasi \\ Telp./Fax : (021) 8254640
}

\author{
Drs. Fauzi, MT \\ Dosen STTD \\ J1. Raya Setu No. 89, Bekasi \\ Telp./Fax : (021) 8254640
}

\author{
Rianto Rili, M.Sc \\ Dosen STTD \\ J1. Raya Setu No. 89, Bekasi \\ Telp./Fax : (021) 8254640
}

\author{
Uriansyah Pratama, MM \\ Dosen STTD \\ J1. Raya Setu No. 89, Bekasi \\ Telp./Fax : (021) 8254640
}

\author{
Noval Seda Winata, M.Sc \\ Dosen STTD \\ J1. Raya Setu No. 89, Bekasi \\ Telp./Fax : (021) 8254640
}

\begin{abstract}
Manggarai Station is a train crossing from Bekasi, Bogor, Tanah Abang, Gambir and Bukit Duri Depots. Related to the increase in the movement of railroad traffic that passes through Manggarai Station such as the presence of airport trains and the addition of the frequency of urban trains demanding the construction of a new Manggarai Station which is planned to be built on an elevated rail way. For this reason, it is necessary to add station service facilities to support the ups and downs of activities and train operations. Due to the increasing frequency of trains, the emplacement will change which results in changes in the track layout at Manggarai Station to unravel the density of rail traffic movements.
\end{abstract}

Keywords: Manggarai Station, railway crossing, safety

\begin{abstract}
ABSTRAKSI
Stasiun Manggarai merupakan persimpangan kereta api dari daerah Bekasi, Bogor, Tanah Abang, Gambir dan Depo Bukit Duri. Terkait dengan bertambahnya pergerakan lalu lintas kereta api yang melintas Stasiun Manggarai seperti adanya kereta bandara dan penambahan frekwensi kereta api perkotaan menuntut adanya pembangunan Stasiun Manggarai baru yang direncanakan akan dibangun secara elevated rail way. Untuk itu diperlukan penambahan fasilitas pelayanan stasiun guna menunjang kegiatan naik turun penumpang dan kegiatan operasi kereta api. Dikarenakan frekwensi kereta api yang akan bertambah, maka emplasemen akan berubah yang
\end{abstract}


berakibat perubahan track layout di Stasiun Manggarai untuk mengurai kepadatan pergerakan lalu lintas kereta api.

Kata Kunci : Stasiun Manggarai, persimpangan kereta api, keselamatan

\section{PENDAHULUAN}

\section{LATAR BELAKANG}

Di Daerah Operasi (Daop) 1 Jakarta khususnya di Provinsi DKI Jakarta, terdapat 5 (lima) stasiun yang digolongkan kelas besar, yaitu Stasiun Jakarta Kota, Stasiun Manggarai, Stasiun Gambir, Stasiun Pasar Senen, dan Stasiun Jatinegara. Stasiun-stasiun tersebut harus memenuhi segala persyaratan standar minimal pelayanan baik untuk naik turun penumpang maupun bongkar muat barang. Stasiun Manggarai merupakan salah satu stasiun yang tersibuk karena selain dilewati oleh kereta api jarak jauh juga sebagai stasiun transit Kereta Rel Listrik (KRL) Commuter Line Jabodetabek. Stasiun Manggarai merupakan persimpangan kereta api dari daerah Bekasi, Bogor, Tanah Abang, Gambir dan Depo Bukit Duri. Dikarenakan frekwensi kereta api yang akan bertambah, maka emplasemen akan berubah yang berakibat perubahan track layout di Stasiun Manggarai untuk mengurai kepadatan pergerakan lalu lintas kereta api. Track layout yang akan berubah total dibangun secara bertahap, karena terkait dengan pergantian atau pergerakan wesel yang beresiko terhadap terjadinya kecelakaan kereta api atau peristiwa luar biasa hebat (PLH). Wesel merupakan titik rawan terjadinya anjlokan kereta api, sehingga pemasangan wesel harus sesuai dengan spesifikasi teknis dan prosedur yang telah ditentukan. Menurut data dari Komite Nasional Keselamatan Transportasi (KNKT) tahun 2017, dalam 3 tahun terakhir (2015 - 2017) telah terjadi peristiwa anjlokan sebanyak 15 kali di seluruh Indonesia termasuk salah satunya di emplasemen Stasiun Manggarai pada tahun 2017.

\section{A. IDENTIFIKASI MASALAH}

Berdasarkan latar belakang tersebut, dapat diidentifikasi permasalahan antara lain:

1. Akan adanya penambahan frekwensi lalu lintas kereta api yang mengakibatkan bertambahnya pergerakan lalu lintas kereta api.

2. Sedang dibangunnya Stasiun Manggarai sehingga terjadi perubahan tata letak wesel. 
3. Perubahan tata letak wesel tersebut akan menambah titik rawan terjadinya anjlokan kereta api.

4. Wesel yang dirangkai dan dipasang harus sesuai dengan prosedur operasional standar (SOP) karena pada daerah wesel ditengarai sering terjadi anjlokan.

\section{B. PERUMUSAN MASALAH}

Dari identifikasi permasalahan tersebut, maka agar penyelesaian masalah tersebut dapat lebih mudah pemecahannya dan hasilnya terukur maka diperlukan perumusan masalah sebagai berikut :

1. Bagaimana kondisi pola operasi perjalanan kereta api di Stasiun Manggarai?

2. Bagaimana kondisi prasana di Stasiun Manggarai?

3. Apa sajakah tingkat kerawanan anjlokan saat tahapan pembangunan track layout Stasiun Manggarai?

4. Bagaimana analisis track layout baru, termasuk wesel di Stasiun Manggarai?

5. Bagaimana evaluasi pembangunan track layout baru di Stasiun Manggarai?

\section{WESEL}

Wesel merupakan konstruksi rel kereta api yang bercabang (bersimpangan) tempat memindahkan jurusan jalan kereta api. Fungsi dari wesel antara lain:

1. Memindahkan jalur kereta api

2. Menghindari tabrakan, karena kereta ada yang bersilang dan disusul

3. Dalam keadaan darurat bisa berfungsi sebagai tempat penampungan kereta mogok

Jenis-jenis wesel yang digunakan antara lain:

1. Wesel biasa, terdiri dari
a. Wesel biasa kiri
b. Wesel biasa kanan

2. Wesel dalam lengkung, terdiri dari:
a. Wesel searah lengkung
b. Wesel berlawanan arah lengkung

3. Wesel tiga jalan, terdiri dari:
a. Wesel tiga jalan searah
b. Wesel tiga jalan berlawanan arah 
c. Wesel tiga jalan searah tergeser

d. Wesel tiga jalan berlawanan arah tergeser

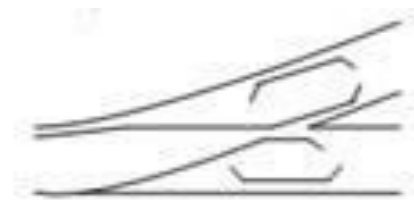

1) Wesel Biasa Kiri

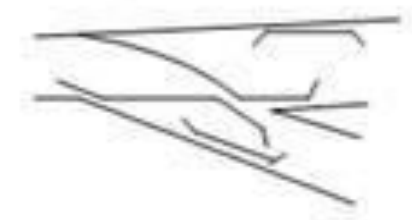

2) Wesel Biasa Searah

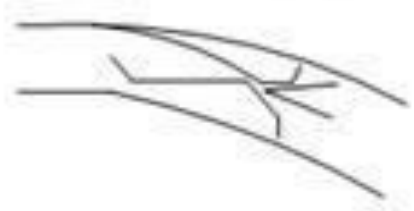

3) Wesel SearahLenghung

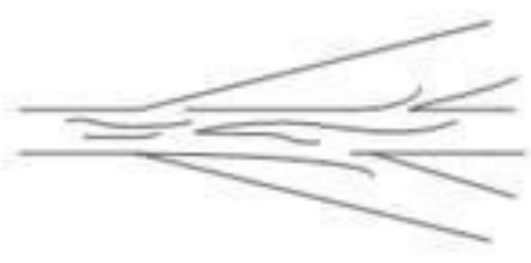

4) Wesel Beriawanan arah

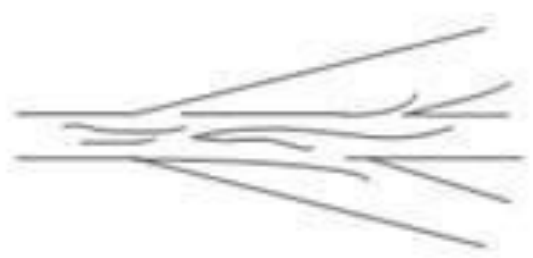

5) W.3 Jalan Searah Tergeser

Jenis wesel Biasa, Wesel Dalam Lengkung dan

Wesel Tiga Jalan

4. Wesel Inggris, terdiri dari:

a. Wesel Inggris penuh

b. Wesel Inggris setengah

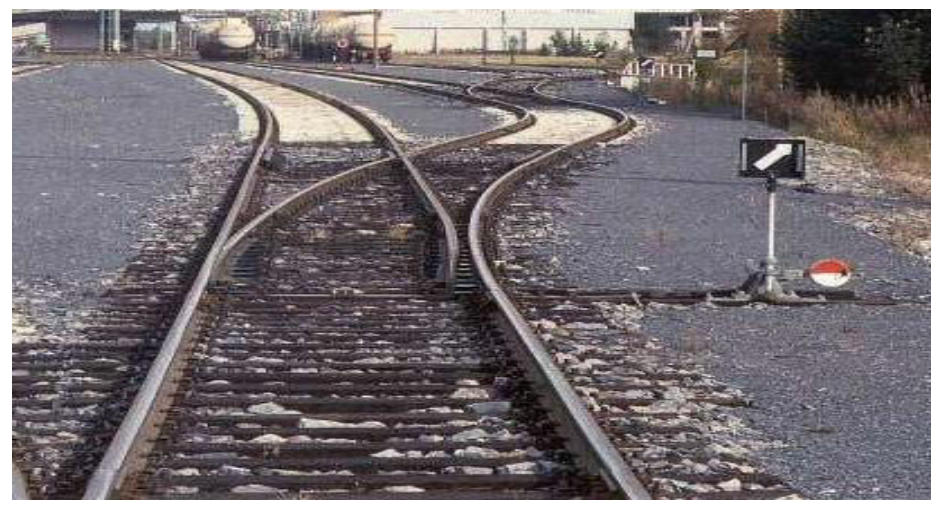

Gambar Wesel Biasa Kanan 


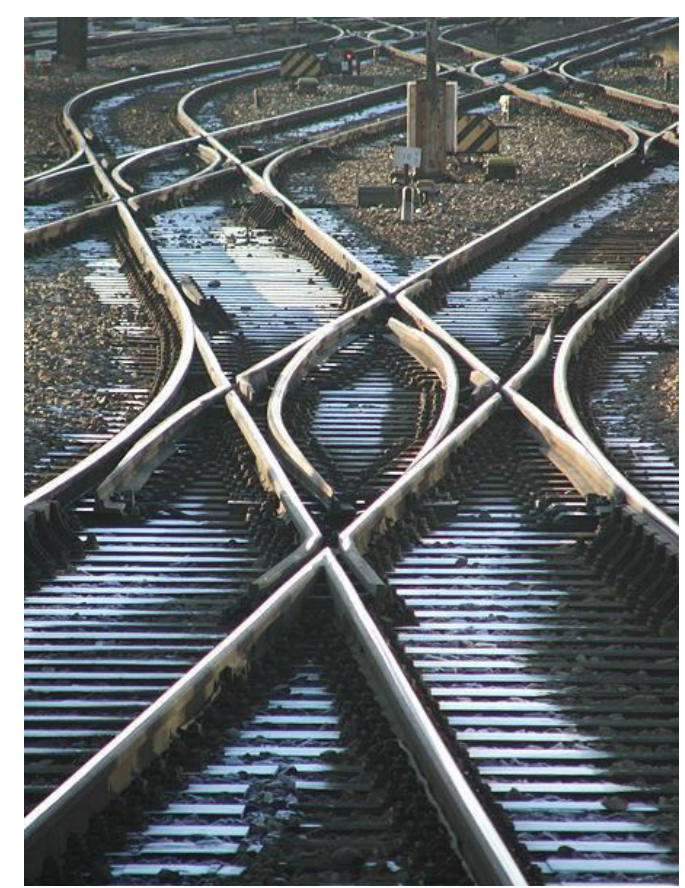

Gambar II.3 Wesel Inggris

\section{B. ANJLOKAN}

Anjlokan merupakan keluarnya kereta dari jalur rel yang dapat disebabkan oleh :

1. Kegagalan mekanik utama pada komponen rel (rel rusak, penambat hilang, bantalan rusak, dan lain sebagainya)

2. Kegagalan mekanik utama pada komponen gigi roda kereta

3. Kesalahan desain atau pengaturan wesel

4. Kesalahan pada geometri jalur rel

5. Kesalahan operasi atau kesalahan sinyal

6. Human error

Selain itu, penyebab kereta anjlok dari rel karena sentakan kecepatan yang tidak rata, karena jarak rel yang sudah berubah (karena pengaruh pergerakan tanah yang tidak stabil), karena ganjalan benda keras diatas rel, atau bisa juga karena sambungan antar rel yang terlepas. Untuk itu perawatan dan pemeliharaan terutama untuk komponen-komponen jalan rel harus dilakukan secara periodik dan teliti.

\section{ARAH PENGEMBANGAN STASIUN MANGGARAI}

Untuk memperbesar kapasitas kereta api yang dapat dilayani sekaligus agar dapat melayani kereta bandara di Stasiun Manggarai, maka dikembangkan dengan membangun 
jalur dwi-ganda (double-double track) lintas Manggarai - Cikarang. Pengembangan tersebut berupa:

1. Stasiun Manggarai akan dijadikan tiga tingkat, tiap tingkat dapat melayani kereta api yang melintas tanpa saling bersinggungan (bergantian).

2. Lantai pertama: terdiri dari 4 jalur KRL Bekasi - Manggarai - Tanah Abang Jatinegara PP, 4 jalur kereta bandara dengan panjang peron cukup untuk menampung 12 kereta.

3. Lantai kedua: dijadikan ruang layanan penumpang dengan luas $9.108 \mathrm{~m}^{2}$ yang dilengkapi dengan lift dan tangga berjalan.

4. Lantai ketiga: terdiri dari 6 jalur kereta api jarak jauh dan 4 jalur KRL Jakarta Kota - Bogor

\section{Stasiun Manggarai Lantai 3}

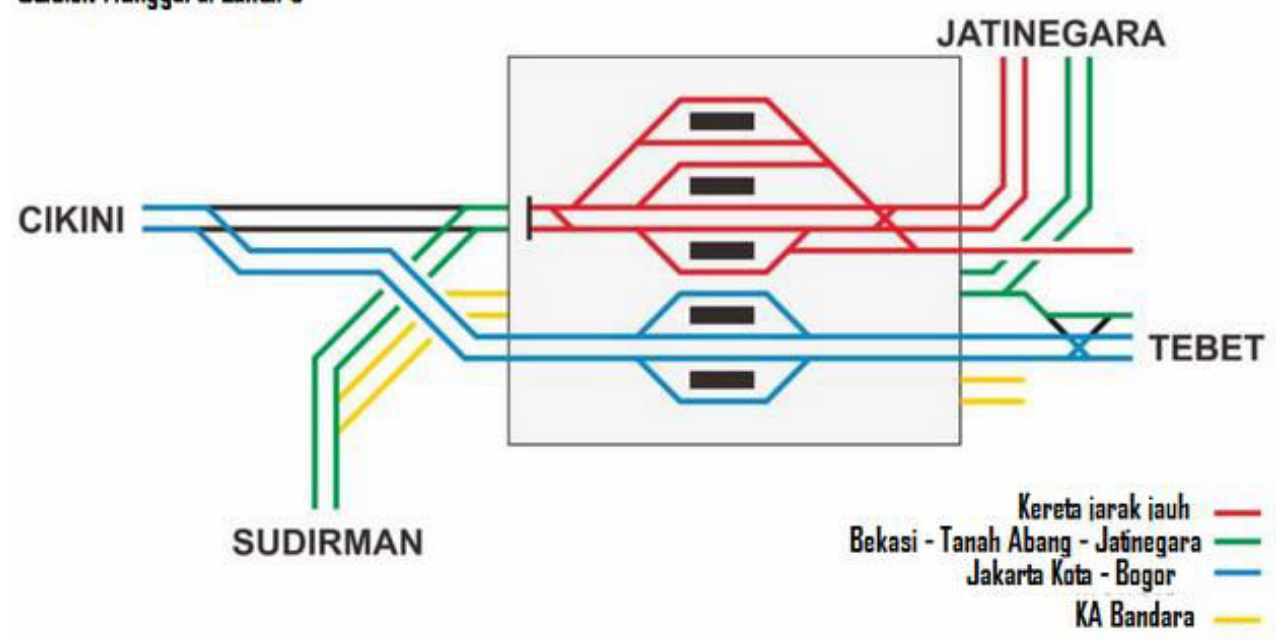

Gambar Rencana Stasiun Manggarai Lantai 3

Dengan dikembangkannya Stasiun Manggarai menjadi 3 lantai dan jalur ganda tersebut, pengaturan perjalanan akan mengalami perubahan sebagai berikut:

1. Kereta api jarak jauh akan mengakhiri perjalanan di Stasiun Manggarai dan sebagian di Stasiun Pasar Senen

2. Kereta api jarak jauh akan dipisah dengan perjalanan KRL jalur Bekasi setelah pembangunan jalur dwi-ganda

3. KRL jalur Bekasi akan terpisah dengan KRL jalur Bogor

4. Kereta bandara akan memiliki rute Manggarai - Duri - Batu Ceper - Bandara Soekarno Hatta. 


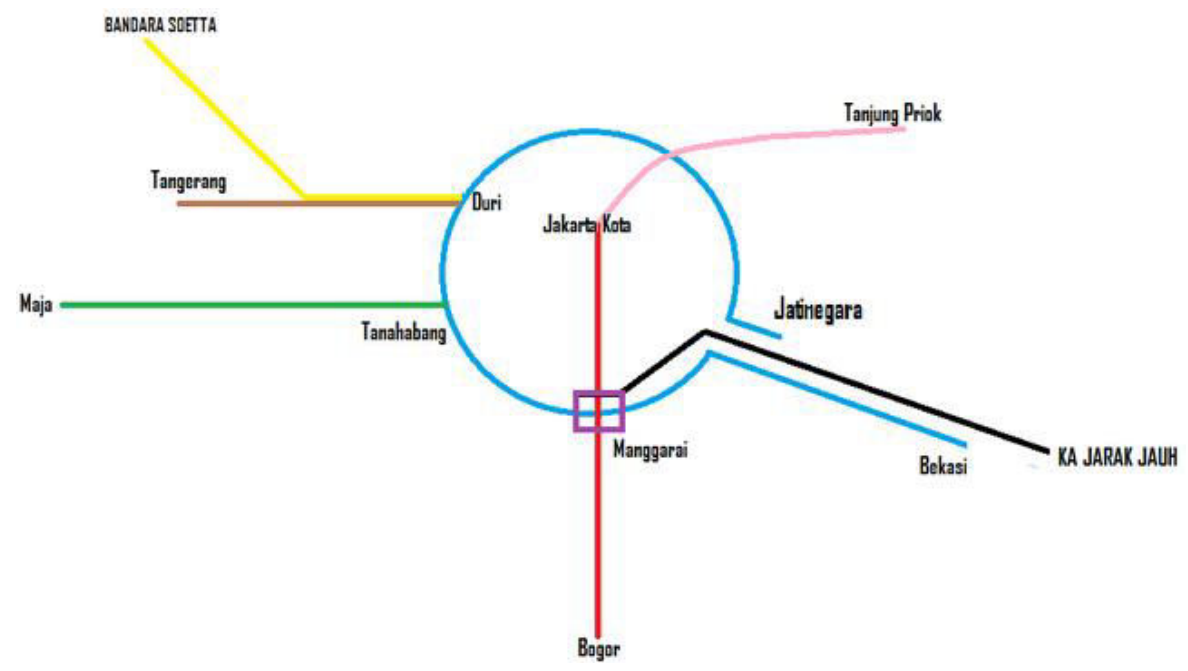

Gambar Rencana Pengaturan Perjalanan di Stasiun Manggarai

\section{ANALISIS DAN PEMBAHASAN}

\section{A. ANALISIS PENYEBAB TERJADINYA ANJLOKAN KERETA API}

1. Analisis penyebab anjlokan terkait sarana

a. Kegagalan mekanik utama pada gigi roda rel.

Pada perencanaan track lay out baru untuk rute dari dan ke Stasiun Manggarai dari arah Bekasi tepatnya antara stasiun Jatinegara dan Manggarai direncanakan dibangun fly over jalur kereta api yang mempunyai alinyemen vertikal sekitar 10 per mil menanjak keatas dengan tujuan Stasiun Tanah Abang, sedang dari arah Bogor juga dibuat jalur secara fly over dengan tujuan langsung ke Jakarta Kota dengan alinyemen vertikal 10 per mil menanjak keatas, sehingga kereta api commuter line akan berjalan tidak sebidang dengan kereta api jarak jauh. Namun dengan adanya fly over tersebut dengan jalur kereta api yang menanjak memungkinkan apabila bogie dan roda kereta tidak terawat dan tidak berfungsi dengan baik, juga bogie serta roda kereta yang kurang sempurna akibat pengereman yang mendadak dan berulang - ulang, maka akan dimungkinkan roda mudah aus dan benjol sehingga dimungkinkan terjadi anjlokan. Sedang sepur yang melayani untuk kereta komuter arah Bekasi - Jatinegara - Tanah Abang direncanakan dilayani sepur satu dan sepur dua, demikian pula arah 
dari Bogor - Depok sampai dengan Jakarta Kota dilayani oleh sepur satu dan sepur dua.

b. Pengoperasian sarana yang tidak sesuai juknis.

Pada perencanaan track lay out baru untuk rute dari dan ke Stasiun Manggarai dari arah Bekasi tepatnya antara Stasiun Jatinegara dan Manggarai direncanakan dibangun fly over jalur kereta api yang mempunyai alinyemen vertikal sekitar 10 per mil menanjak keatas dengan tujuan Stasiun Tanah Abang. Sedangkan dari arah Bogor juga dibuat jalur secara fly over dengan tujuan langsung ke Jakarta Kota dengan alinyemen vertikal 10 per mil menanjak keatas pula, sehingga kereta api Commuter Line akan berjalan tidak sebidang dengan kereta komuter lainnya serta kereta api jarak jauh. Namun dengan adanya fly over tersebut jalur kereta api yang menanjak memungkinkan apabila pengoperasian kereta tidak sesuai dengan ketetuan dan standar operasional yang berlaku, misal kereta sering terlambat masuk depo perawatan harian, bulanan dan tahunan yang terkait dengan hubungan antara body kereta dan bogie serta roda. Disamping itu juga terlalu sering melakukan pengereman mendadak dan berulang ulang, sehingga akan mengakibatkan kereta berjalan tidak sempurna. yang menyebabkan kemungkinan akan terjadi anjlokan. Sedang sepur yang melayani untuk kereta komuter arah Bekasi - Jatinegara - Tanah Abang direncanakan dilayani sepur satu dan sepur dua,demikian pula arah dari Bogor - Depok sampai dengan Jakarta Kota dilayani oleh sepur satu dan sepur dua.

2. Analisis penyebab anjlokan terkait prasarana

a. Kegagalan mekanik komponen jalan rel.

Pada perencanaan track lay out baru untuk rute dari dan ke Stasiun Manggarai dari arah Bekasi tepatnya antara Stasiun Jatinegara dan Manggarai direncanakan dibangun fly over jalur kereta api yang mempunyai alinyemen vertikal sekitar 10 per mil menanjak keatas dengan tujuan Stasiun Tanah Abang. Sedangkan dari arah Bogor juga dibuat jalur secara fly over dengan tujuan langsung ke Jakarta Kota dengan alinyemen vertikal 10 per mil menanjak keatas, sehingga kereta 
api commuter line akan berjalan tidak sebidang dengan kereta api jarak jauh. Namun dengan adanya fly over tersebut dengan jalur kereta yang menanjak memungkinkan apabila seluruh struktur komponen dari jalur kereta api seperti rel, penambat, bantalan dan balas jika tidak terpasang dan terbangun dengan baik (seperti sistem sambungan yang kurang benar yang terkait dengan pengelasan dan pemasangan baut yang kurang benar). Selain itu adalah kondisi struktur badan jalan yang kurang baik serta struktur komponen yang berkaitan dengan harmonisasi antara jalur mendatar kearah yang menanjak dan menurun serta pengoperasian wesel yang kurang sempurna akan dimungkinkan terjadi anjlokan. Sedang sepur yang melayani untuk kereta komuter arah dari dan ke Bekasi - Jatinegara - Tanah Abang kemungkinan direncanakan akan dilayani sepur satu dan sepur dua, demikian pula arah dari dan ke Bogor - Depok sampai dengan Jakarta Kota dilayani oleh sepur satu dan sepur dua melalui Stasiun Manggarai.

b. Kegagalan pada geometrik jalan rel

Pada perencanaan track lay out baru untuk rute dari dan ke Stasiun Manggarai dari arah Bekasi tepatnya antara Stasiun Jatinegara dan Manggarai direncanakan dibangun fly over jalur kereta yang mempunyai alinyemen vertikal sekitar 10 per mil menanjak keatas dengan tujuan Stasiun Tanah Abang. Sedangkan dari arah Bogor juga dibuat jalur secara fly over dengan tujuan langsung ke Jakarta Kota dengan alinyemen vertikal 10 per mil menanjak keatas, sehingga kereta api commuter line akan berjalan tidak sebidang dengan kereta api jarak jauh. Namun dengan adanya fly over tersebut dengan jalur kereta yang menanjak memungkinkan apabila alinyemen vertikal yang tidak rata terutama pada daerah sambungan pada struktur balok memanjang dan alinyemen horizontal terutama pada daerah lengkung. Terkait dengan balok memanjang dan melintang yang kurang baik maka akan mengakibatkan kesulitan dalam pemeliharaan jalur sehingga akan berakibat kemungkinkan terjadi anjlokan. Sedang sepur yang melayani untuk kereta komuter arah Bekasi - Jatinegara - Tanah Abang direncanakan dilayani sepur satu dan sepur dua, demikian pula arah 
dari Bogor - Depok sampai dengan Jakarta Kota dilayani oleh sepur satu dan sepur dua.

c. Analisis penyebab anjlokan terkait sumber daya manusia

1) Kegagalan operasional kereta api terkait dengan ketaatan sistem dan prosedur.

Walaupun track lay out yang baru telah direncanakan dengan matang dan nilai stabilitas dari struktur juga telah diperhitungkan dengan teliti dan cermat serta dinyatakan stabil dan aman, track lay out baru tersebut juga telah terbangun sesuai dengan dokumen perencanaan, namun apabila dalam pelaksanaan operasi kereta api baik commuter line dan kereta api jarak jauh tidak sesuai dengan sistem dan standar operasional yang ada maka dimungkinkan juga akan terjadi anjlokan. Selain itu bila pada pelaksanaan pengoperasian kereta api terutama untuk yang menanjak atau menurun dan atau yang berjalan melalui daerah lengkung, bila tidak taat pada sistem dan prosedur operasional yang telah ditentukan, maka dimungkinkan akan terjadi insiden anjlokan, misal melaju dengan tidak memperhatikan sinyal masuk dan keluar serta tidak memperhatikan rambu - rambu yang ada kemudian melakukan pengereman secara mendadak. Selain itu melalui struktur bangunan wesel yang pengoperasiannya kurang sempurna dan teliti juga akan mengakibatkan terjadinya anjlokan kereta api tersebut.

2) Kegagalan operasional kereta api terkait dengan perilaku Walaupun track lay out yang baru telah direncanakan dengan matang dan nilai stabilitas dari struktur juga telah dihitung dan dinyatakan stabil dan aman, track lay out baru tersebut telah terbangun sesuai dengan dokumen perencanaan, namun apabila dalam pelaksanaan operasi kereta api baik commuter line maupun kereta api jarak jauh, bila perilaku dari masinis dan atau petugas perjalanan kereta api yang tidak sesuai dan kurang disiplin dalam pelaksanaan tugas misal bermain-main dengan alat komunikasi pada saat melakukan pekerjaannya, dapat dimungkinkan juga akan 
terjadi anjlokan pada kereta api tersebut. Anjlokan dapat terjadi terutama pada pergantian arah kereta api melalui wesel pada jalur yang menanjak, menurun serta berjalan melalui daerah lengkung dan petugas tersebut lalai dalam melaksanakan tugasnya dengan baik, maka dimungkinkan pula akan terjadi insiden anjlokan. Sebagai contoh ketika melaju dengan tidak memperhatikan sinyal masuk dan keluar serta rambu - rambu yang ada kemudian melakukan pengereman mendadak. Selain itu melalui struktur bangunan wesel yang pengoperasiannya kurang sempurna dan teliti juga akan mengakibatkan terjadinya anjlokan kereta api tersebut.

\section{B. ANALISIS PENCEGAHAN ANJLOKAN KERETA API}

1. Analisis pencegahan anjlokan terkait sarana.

Pencegahan anjlokan terkait dengan operasi penggunaan sarana yang sesuai dengan sistem dan prosedur serta ketaatan terhadap pelaksanaan pemeriksaan dan pemeliharaan/perawatan roda, bogie dan sistem komponen rem secara berkala dan terus menerus melalui pemeliharaan baik harian, mingguan dan tahunan termasuk juga dengan ketaatan terhadap penggantian suku cadang dari sarana terutama terkait dengan suku cadang untuk penggantian rem, roda dan bogie.

2. Analisis pencegahan anjlokan terkait prasarana.

Pencegahan anjlokan yang terkait prasarana adalah pentingnya pelaksanaan pemeriksaan dan pemeliharaan seluruh komponen jalur termasuk geometri jalur dan badan jalur kereta api serta prasarana penunjang lainnya seperti drainase, lereng sekitar jalur kereta api baik yang diperkuat oleh turap baja, kayu dan dinding penahan tanah (yang berfungsi sebagai penguat lereng di darat dan di sekitar pantai dan danau). Karena apabila struktur penunjang tersebut tidak diperiksa dan dipelihara dengan baik, maka akan menimbulkan longsoran dan akibatnya terjadi anjlokan. 


\section{ANALISIS TRACK EKSISTING TERHADAP TRACK LAY OUT BARU}

Dari hasil survei lapangan yang terdiri dari survei inventarisasi fasilitas prasarana dan survei karakteristik pola perjalanan yang telah berjalan dan berlaku saat ini, maka dapat dijelaskan pola operasi sebagai berikut:

\section{Track eksisting}

Sepur 1 (satu), sepur 2 (dua), dan sepur 3 (tiga) diberikan pelayanan melalui wesel kiri untuk merubah arah di sebelah kanan dari arah Manggarai untuk menuju Stasiun Cikini sampai dengan Gondangdia - Gambir - Juanda Sawah Besar - Mangga Besar - Jayakarta -Jakarta Kota. Selain itu melalui wesel Inggris dari sepur 1 (satu) dan sepur 2 (dua) dapat melayani kereta untuk tujuan Tanah Abang, termasuk pula untuk sepur 5 (lima) dan sepur 6 (enam).

Sepur 4 (empat), sepur 5 (lima) dan sepur 6 (enam) melayani kereta dari arah Jakarta Kota - Cikini - Manggarai dan berlanjut ke arah Bekasi dan Depok serta Bogor.

Sepur 7 (tujuh) dan sepur 8 (delapan) untuk kereta bandara ke arah Tanah Abang - Soekarno Hatta, sedang untuk menuju ke arah Bekasi dan Depok, kereta bandara harus dilangsir dahulu dapat menggunakan sepur 3 (tiga), sepur 4 (empat) dan sepur 5 (lima).

2. Track lay out baru

Usulan track lay out baru direncanakan untuk kereta bandara dan kereta jarak jauh akan disediakan di lantai satu, sedangkan lantai dua untuk KRL dari arah Depok dan Bogor ke arah Jakarta Kota serta KRL dari arah Bekasi dan Cikarang ke arah Tanah Abang. Hal ini diatur sedemikian rupa karena apabila dari arah Bekasi dan Cikarang akan dibuat ke arah Jakarta Kota akan terjadi kesulitan untuk arah Bogor dan Depok yang menuju ke Stasiun Jatinegara. Selain itu apabila dari arah Bekasi dan Cikarang langsung ke arah Tanah Abang disediakan wesel kiri dari arah Manggarai, maka KRL yang dari Depok dan Bekasi bisa beroperasi ke arah Jatinegara.

3. Usulan perubahan pertama terkait track lay out baru, yaitu dibuat dua lantai dimana lantai satu at grade (di permukaan tanah) untuk kereta bandara dan kereta jarak jauh, sedangkan lantai dua untuk KRL yang dapat beroperasi langsung dari Bekasi/Cikarang dan Depok serta Bogor ke arah Jakarta Kota. 
4. Usulan perubahan kedua terkait track lay out baru, yaitu dibuat track terpisah di lantai dua sehingga dari arah Depok dan Bogor serta Bekasi dan Cikarang dapat langsung ke arah Jakarta Kota, sedangkan lantai satu untuk kereta bandara dan kereta jarak jauh.

5. Usulan perubahan ketiga terkait track lay out baru, yaitu KRL menggunakan track lama sehingga arah ke Jakarta Kota baik dari arah Bekasi dan Cikarang serta dari Depok dan Bogor dapat langsung ke arah Jakarta Kota sedang kereta bandara dan kereta jarak jauh menggunakan elevated track (jalur layang).

\section{KESIMPULAN DAN SARAN}

\section{A. KESIMPULAN}

Berdasarkan hasil analisis dan pembahasan terkait pencegahan anjlokan terkait perubahan track layout di Stasiun Manggarai, dapat disimpulkan:

1. Penyebab terjadinya anjlokan yang disebabkan oleh sarana antara lain dikarenakan adanya kegagalan pada mekanik sarana, pengoperasian yang tidak sesuai dengan petunjuk teknis.

2. Penyebab terjadinya anjlokan yang disebabkan oleh prasarana dikarenakan kegagalan mekanik komponen jalan rel, kegagalan pada geometrik jalan rel.

3. Penyesuaian terhadap track lay out baru, dapat dilaksanakan dengan mempertimbangkan penggunaan wesel inggris untuk mencegah anjlokan dan penyesuaian track emplasemen khusus kereta bandara dengan tetap mempertimbangkan kebutuhan operasional perjalanan kereta api saat ini serta rencana pengembangan untuk masa yang datang.

4. Kepuasan pengguna jasa kereta api khususnya KRL di stasiun manggarai saat ini baik untuk lintas Bogor - Jakarta Kota maupun lintas Cikarang - Jakarta Kota masih relative tinggi yaitu diatas $60 \%$. 


\section{B. SARAN}

Beberapa hal yang perlu untuk disarankan dari hasil analisis dan pembahasan yaitu:

1. Sebagai pencegahan anjlokan yang disebabkan oleh sarana diperlukan ketaatan terhadap pelaksanaan pemeriksaan dan pemeliharaan/perawatan roda, bogie dan sistem komponen rem

2. Sebagai pencegahan anjlokan yang disebabkan prasarana pelaksanaan pemeriksaan dan pemeliharaan seluruh komponen jalur termasuk geometri jalur dan badan jalur kereta api serta prasarana penunjang lainnya

3. Perlu dilakukan penyesuaian terhadap track lay out baru sehingga bisa meminimalisir titik rawan anjlokan, dan kebutuhan operasional perjalanan kereta api saat ini maupun yang akan datang masih dapat terakomodir.

4. Guna mempertahankan dan meningkatkan tingkat kepuasan pengguna kereta api perlu dilakukan penyesuaian track lay out sehingga waktu operasinal kereta api relative lebih cepat.

\section{DAFTAR PUSTAKA}

Undang-Undang No.23 Tahun 2007 Tentang Perkeretaapian

Peraturan Menteri Tahun 2017 Tentang Tata Cara dan Standar Pembuatan Grafik Perjalanan Kereta Api

Peraturan Menteri No. 48 Tahun 2015 Tentang Standar Pelayanan Minimum Angkutan Orang dengan Kereta Api

Peraturan Pemerintah No. 72 Tahun 2009 Tentang Penyelenggaraan Lalu Lintas dan Angkutan Kereta Api

Komite Nasional Keselamatan Transportasi, 2017, Capaian Kinerja Investigasi Keselamatan Transportasi Tahun 2017 